\title{
EFFECT OF INLET AIR TEMPERATURE ON COMBUSTION, PERFORMANCE AND EMISSIONS OF GASOLINE DIRECT INJECTION (GDI) ENGINE FUELLED BY LPG FUEL
}

\author{
Mohanad Aldhaidhawi ${ }^{1}$ \\ mohanadhamazah@gmail.com
}

Oras Khudhayer Obayes ${ }^{2}$

mujtabaoras25@gmail.com

\author{
Muneer Najee ${ }^{3}$ \\ muneernajee@yahoo.com
}

1,3 Al-Furat Al-Awsat Technical University (ATU), Technical Institute of Kufa, Iraq

${ }^{2}$ Al-Furat Al-Awsat Technical University (ATU), Technical Institute of Babylon, Iraq

\section{ABSTRACT}

In the present work, the direct-injection petrol engine (GDI) combustion, emissions and performance at different engine speeds $(1500,2000,2500$ and $3000 \mathrm{rpm})$ with a constant throttle position have been studied. The fuel considered in this work is liquid petroleum gas (LPG) and gasoline. The software adopted in all simulations by the AVL BOOST 2016. A Hyundai 2.0 liter, 16 valves and 4 cylinders engine with a compression ratio 17.5:1 is used. The effect of several inlet air temperatures $\left(0,10,20,30,40\right.$ and $\left.50{ }^{\circ} \mathrm{C}\right)$ on the engine performance, combustion and emissions are also studied. The results show that the increase in the inlet air temperature leading to increase the peak fire temperature, brake specific fuel consumption (BSFC) and nitrogen oxide (NOx). However, this process results in a reduction in the peak fire pressure, combustion period (duration), brake power and brake torque. The maximum fire temperature and maximum specific fuel consumption can be achieved when the engine speed is $3000 \mathrm{rpm}$ and the inlet air temperature is $50^{\circ} \mathrm{C}$.

Keywords: Spark Ignition, LPG fuel, GDI engine, Engine performance

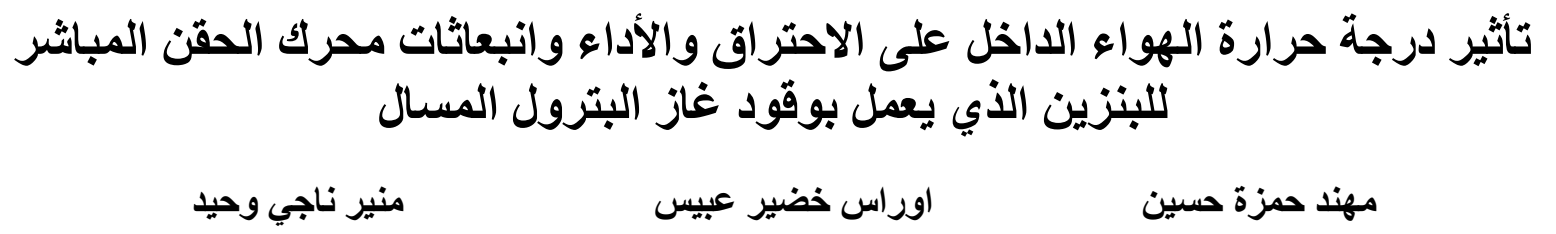

الخلاصة

يتضدن البحث الحالي دراسة حول الاحتراق في محرك البنزين بالحقن المباثر والانبعاثات و أدائه بسرعات مختلفة

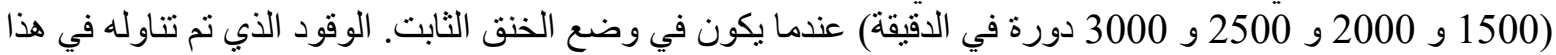

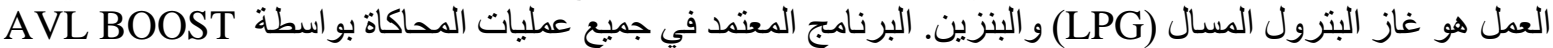

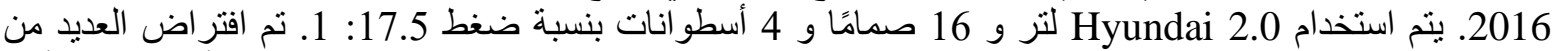
درجات حرارة الهو اء الداخل (0 ، 10 ، 20 ، 30 ، 40 ، 40 ، 50 درجة مئوية) في النموذج لمر اقبة تأثير ها على أداء

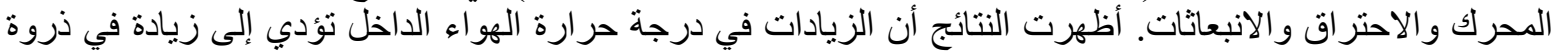

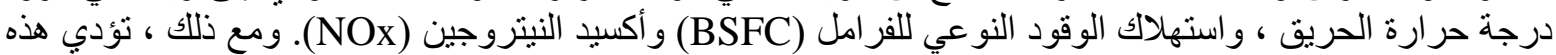

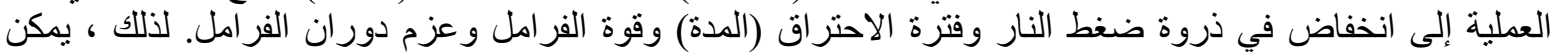

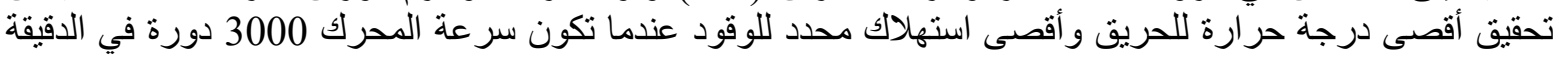
ودرجة حرارة الهو اء الداخل 50 درجة أحة مئوية. 


\section{INTRODUCTION}

Internal combustion engines consider one of the most efficient methods of producing energy that uses at different stages of life. Petrol engines operate according to internal combustion principles and are widely applied in real applications such as transport (especially vehicles), power generation, etc. (Abdalla AN et al. (2019), Ali OM. (2019), Ahmed et al (2019) and Abdalla AN et al 2019). There are different types of fuels that could be used in internal combustion engines based on energy savings, costs and properties. Over the past two decades, the use of liquefied petroleum gas (LPG) has become popular in commercial vehicles. Several reasons attract researchers to do a lot of effort to develop LPG engines. All volume percentage and component analysis of a composition of LPG fuel were supplied at the Al-Hillah gas facility and these values illustrated in this investigation (Ahmed Shakir 2016). The process of extracting LPG-flammable gas is simpler if it is compared to other types of fuel because it does not need to be refined. The main components of the LPG are propane and butane, in the form of a mixture. The LPG is possible to operate with a greater compression ratio, which leads to better performance due to a higher number of octane (105) than gasoline (91-97) "Alternative Vehicle Fuels," (2004). Studies have shown that when fuel (LPG) is used in internal combustion it leads to higher thermal efficiency and greater fuel economy compared to lead-free petrol (A.P.F. Yoong et al (2004). C. L. Myung et al., 2012) conducted an experimental study on a light vehicle LPG-GDI-engine to investigate toxic emissions characteristic. The study carried out three emission test cycles: the federal test method (FTP75), the road fuel economy test (HWFET) and the latest European driving cycle (NEDC). The results were obtained with good agreement in all test cycles. These reasons are linked to fuel consumption and exhaust emissions (Haykan Bayraktar et al,2005). In addition, the low amount of carbon and the high number of fuel octanes (LPGs) lead to a decrease in carbon dioxide (CO2) which represents good property compared to other types of fuel (Kitae Yeom et al ,2007). This is mainly due to the increasing octane rating without a knock and that allows to magnify engine compression ratio. In addition, for other fuel types, the (LPG) fuel has a higher heating quality in the atmosphere with a pressure range of 0.7 to $0.8 \mathrm{MPa}$ (Kihyung Lee et al, 2005). LPG fuel is actually represented as one of the main renewable fuels and as an appropriate energy source based on its characteristics, such as a higher hydrogen/carbon ratio and no harmful aromatics in emissions (L. Raslavičius, et al (2014) and M. Masi (2012). M. Farrugia et al.,2014) also noted that the LPG had an average reduction of approximately $35.7 \%$ and $56.5 \%$ in $\mathrm{HC}$ and $\mathrm{CO}$ emissions. Over the past decade, it has been noted that fuel (LPG) as a source of alternative fuel for motor vehicles (Philip Price et al,2004), therefore, around four million vehicles currently operate on fuel (LPG) worldwide. The LPG emissions from vehicles are slightly lower than those of conventional fuel vehicles .In addition, in the Japanese taxi fleet, 94\% of them operate on fuel (LPG) and approximately half of the millions of Australian vehicles apply it (Ristovski, Z.D. et al,2005). A range of different technologies to use LPG as fuel were illustrated in previous studies (Ross Ryskamp,2017). Schifter, I. et al. (2011) developed algorithms for approximately 28000 vehicles working in fuel (LPG) in the metropolitan area of the Valley of Mexico (MZVM). Many of these vehicles have been predominantly light, moderate and heavy vehicles were initially fuelled with petrol were modified to work with (LPG) using licensed and certified conversion kits due to its lower carbon content than gasoline which provides virtually minimum particulate emissions and reduces NOx emissions(Schifteret al.2011). The LPG grows applications is widely accepted by governments and car manufacturers. Several research studies have recorded effective pollution results when using fuel (LPG) as an alternative energy source in spark ignition engines. In addition, direct injection technology offers additional benefits for particular and enhanced brake thermal efficiency by adding (LPG) fuel to develop the spark-ignition engines. Snelgrove, D.G et al. (1996) indicated that during the European test cycle at 25oC, 
LPG vehicle emissions were significantly recorded in hydrocarbons (HC) of $40 \%$ less, carbon monoxide (CO) emissions by $65 \%$ lower and carbon dioxide (CO2) as significantly decreased. This project's goal is to report is to offer analytical information on the effects of air temperature input on the combustion, performance and emissions of GDI engine operating on the LPG at different speeds.

\section{SIMULATION PROCEDURES}

\section{Fuel}

A mixture of different categories of hydrocarbons (ethane, propane, butane and Pentane) is a term that describes a liquefied petroleum gas (LPG). The volume percentage and component analysis of a composition of LPG fuel were supplied at the Al-Hillah gas facility where table (1) (Ahmed Shakir,2016) shows these results.

\section{LPG FUELING TECHNOLOGIES}

In the case of internal combustion engines, there is a range of technologies to use LPG as fuel, these inventions differ in terms of cost and complexity and also in performance and terms of efficiency. Currently, the application of LPG has progressed carefully for all engines using petrol fuel (Ross Ryskamp,2017).

\section{Port Fuel Injection (PFI)}

Fuel injection at the port Compared to single-point fuel systems, LPG provides a number of advantages. PFI technologies are practically a carbon copy of multi-port electronic control fuel injection control systems, which have been widely utilized in petrol engines for the past two decades. In actuality, most vehicles with LPG port injection were originally designed for gasoline and then converted to operate on LPG. In additionally, original equipment manufacturers (OEMs) offer a variety of LPG options, mainly in the European and Asian markets (Ross Ryskamp,2017).

\section{Direct Fuel Injection (DFI)}

Over the last decade, the number of vehicles configured with spark-ignition petrol (GDI) direct-injection engine has increased considerably. Depending on their energy efficiency advantages, the majority of automotive OEMs mainly submit GDI engines. For the direct injection of fuel within the combustor, GDI engines employ high-pressure fuel injection and a cylinder fuel injector. In contrast to PFI systems, this provides more accurate control of the fuel injection process. Without octane-high gasoline, this improved injection control enables injection strategies that restrict knocking also enhances compression ratios. Through the same inference, forced induction processes, such as turbocharge and overload, are more acceptable to GDI engines. GDI engines typically use several injection incidents to eliminate engine knock and to allow a higher compression ratio. Compared to PFI engines, this technique will be produced in a more stratified mixture of air and fuel that offers a longer mixing time of air and fuel and therefore mixes very homogeneously. The LPG has an intrinsic advantage over particle formation compared to petrol used in DI engines. In the combustion chamber, greater volatility of LPG encourages mixing, producing minimum air and fuel that reduces the locally rich locations related to the development of carbon-impure molecules that occur under incomplete hydrocarbon combustion. Compared to gasoline, the low carbon intensity of LPG reduces its ability to produce soot and limits CO2 production (Ross Ryskamp,2017).

\section{EXPERIMENTAL SETUP}

A four-cylinder, four-stroke GDI engine is connected to an eddy-current dynamometer and a load controller, as shown in figure (1) used in this work. The primary engine characteristics 
are listed in Table (2). Various devices have been installed in the engine to measure engine output parameters. Type $\mathrm{K}$ thermocouple is used to measure the exhaust and intake temperature. A Kistler 6061B pressure sensor with a sensitivity of $25 \mathrm{pC} / \mathrm{bar}$ is used to measure cylinder pressure. For each parameter, the experimental analysis was conducted three times and the average was taken into account. The exhaust emissions were measured using an IMR 1000 gas analyzer. The engine cylinder pressure recorded at an engine speed of 1500 revolutions/min in a complete throttle position when operating on gasoline fuel.

\section{MODEL ANALYSIS}

AVL WORKSPACE is a computer simulation that is used to investigate the output of internal combustion engines under various operating situations. This program offers a variety of fuel options, including diesel, gasoline, hydrogen, ethanol, propane, and methane. The AVL Boost software was used to demonstrate the combustion, performance, and emissions of an LPGfueled direct-injection engine (GDI). The model was first optimized using AVL documentation (AVL BOOST theory and user guide V2016) (Snelgrove, D.G et al.1996), and then updated based on the obtained data to reach a good agreement with the experimental data. As shown in Figure (2), engine components such as system boundaries, air filter, suction manifold, cylinder geometry, exhaust pipe, and catalyst shape were selected based on engine dimensions and integrated with the program interface. Before it functioned, the commencement of the injection, the air mass flow rate, and the fuel injection rate were all measured experimentally and then incorporated into the programming. As sub-models, the Vibe two-zone combustion model and the Woschni 1990 heat transfer model were chosen. Table (2) summarizes the key engine specifications.

\section{MATHEMATICAL MODEL}

The first law of thermodynamics is used to carry out the modelling. According to the first law of thermodynamics, the energy balance for an open system can be expressed as (Snelgrove, D.G et al.1996):

$$
\frac{d\left(m_{c} \cdot u\right)}{d \theta}=-p \frac{d v}{d \theta}+\frac{d Q_{F}}{d \theta}-\sum \frac{d Q_{w}}{d \theta}-h_{B B} \cdot \frac{d m_{B B}}{d \theta}+\sum \frac{d m_{i}}{d \theta} h_{i}-\sum \frac{d m e}{d \theta} h-q_{e v} \cdot f \cdot \frac{d m_{e v}}{d t}
$$

where:

$$
\begin{aligned}
& \frac{d\left(m_{c} \cdot u\right)}{d \theta} \\
& -p \frac{d v}{d \theta} \\
& \frac{d Q_{F}}{d \theta} \\
& \sum \frac{d Q_{w}}{d \theta} \\
& h_{B B} \cdot \frac{d m_{B B}}{d \theta} \\
& d m_{e} \quad \text { a mass element is ejected from the cylinder } \\
& f
\end{aligned}
$$$$
\text { internal energy changes in the cylinder }
$$$$
\text { work with a piston }
$$$$
\text { heat input from the fuel }
$$$$
d m_{i} \quad \text { a flow of mass into a cylinder }
$$

wall heat losses

below-by enthalpy flow

a percentage of the cylinder charge's evaporation heat. 
$m_{e v}$

Fuel for evaporation.

\section{Instantaneous Cylinder Volume}

The provided equation Snelgrove, D.G et al. (1996) is used to compute the engine cylinder volume (instantaneous volume) at any crank angle.

$$
\begin{aligned}
& S=(r+l) \cdot \cos \psi-r \cdot \cos (\psi+\alpha)-l \cdot{\sqrt{1-\left(\frac{r}{l} \cdot \sin (\psi+\alpha)-\frac{e}{l}\right)^{2}}}^{2} \\
& \psi=\arcsin \left(\frac{e}{r+1}\right)
\end{aligned}
$$

Where $\mathrm{S}$ is the piston distance from TDC, $\mathrm{r}$ is the crank radius, 1 is the con road length, $\mathrm{c}$ is the crank angle between vertical crank position and piston TDC position, $\mathrm{e}$ is the piston pin offset, and an is the crank angle relative to TDC.

\section{Heat Release Rate}

Because the combustion process in a diesel engine is thought to be exceedingly complex and heterogeneous, it is represented using the Mixing Controlled Combustion (MCC) model, as illustrated in Equations (Snelgrove, D.G et al.,1996):

$\frac{d Q \text { total }}{d \theta}=C_{\text {comb }} \cdot f_{1}\left(m_{F}, Q_{M C C}\right) \cdot f_{2}(k, V)$

where

$$
\begin{aligned}
& f_{1}\left(m_{F}, Q\right)=\left(m_{F}-\frac{Q_{M C C}}{L C V}\right) \cdot\left(w_{\text {oxygen,available }}\right)^{C_{E G R}} \\
& f_{2}(k, V)=C_{\text {Rate }} \cdot \frac{\sqrt{k}}{\sqrt[3]{V}}
\end{aligned}
$$

where:

QMCC cumulative heat release for the mixture controlled combustion [kJ],

$C_{C o m b}$ combustion constant $[\mathrm{kJ} / \mathrm{kg} / \mathrm{deg} \mathrm{CA}]$,

$C_{\text {Rate }}$ mixing rate constant $[\mathrm{s}]$,

$K$ local density of turbulent kinetic energy $\left[\mathrm{m}^{2} / \mathrm{s}^{2}\right]$, $m_{F}$ vaporized fuel mass (actual) $[\mathrm{kg}]$,

$L C V$ lower heating value $[\mathrm{kJ} / \mathrm{kg}]$,

$\mathrm{V}$ cylinder volume $\left[\mathrm{m}^{3}\right]$,

$\alpha$ crank angle [deg CA] ,

w Oxygen available, mass fraction of available Oxygen (aspirated and in EGR) at SOI

CEGR influence constant

\section{Ignition Delay}

The time between the initiation of fuel injection and the onset of combustion is known as ignition delay. Delay in starting the engine is calculated used the Andree and Pachernegg equation (Snelgrove, D.G et al. 1996): 


$$
\frac{d I_{i d}}{d \theta}=\frac{T_{U B}-T_{r e f}}{Q_{r e f}}
$$

Where $I$ is the ignition delay integral $[-], T$ is the reference temperature $[K], T_{U B}$ is the unburned zone temperature $[\mathrm{K}]$, and $\mathrm{Q}$ is the reference activation energy.

\section{Heat Transfer}

In this work, the Woschni equation was used to calculate the coefficient of heat transfer between the gases created by the chemical process within the combustion chamber and the cylinder wall, as indicated in equation (Snelgrove, D.G et al. 1996):

$$
\alpha w=130 D^{-0.2} \cdot p_{c}^{0.8} \cdot T_{c}^{-0.53} \cdot\left\{c_{1} \cdot c_{m} \cdot\left[1+2\left(\frac{V_{T D C}}{V}\right)^{2} I M P^{-0.2}\right]\right\}^{0.8}
$$

IMEP indicated mean effective pressure, $\mathrm{V}$ TDC TDC volume in the cylinder, $\mathrm{V}$ actual cylinder volume, $\mathrm{c}$ m mean piston speed, $\mathrm{C}_{1}=2.28+0.308 \cdot \mathrm{c} \mathrm{u} / \mathrm{Cm}, \mathrm{c} \mathrm{u}$ circumferential velocity.

\section{RESULTS AND DISCUSSION \\ Cylinder Pressure}

Figure (3) illustrates the pressure variations in the cylinders as a function of crank angle. The GDI engine's experimental and simulation results were tested at a speed of $1500 \mathrm{rpm}$ in a constant acceleration position using gasoline fuel at a temperature of $30{ }^{\circ} \mathrm{C}$ inlet air. There is a strong agreement between the simulation and the experimental trace, as illustrated in this figure, with a maximum relative divergence of $1.02 \%$ for peak fire pressure.

\section{Peak Fire Pressure}

The highest pressure on an engine cylinder during the combustion process is known as peak fire pressure. Figure (4) shows the influence of varying inlet air temperatures on the combustion of the GDI engine as peak fire pressure with engine speed. This figure appears that the highest fire pressure is decreasing when engine speed increases at any inlet air temperatures. This behavior may be due to decreased volumetric efficacy.

\section{Peak Fire Temperature}

The greatest temperature reached by an engine cylinder during combustion phases is known as the peak fire temperature. As known, the peak fire temperature has a direct effect on the formation of emissions. The impact of many variables inlet air temperatures on the combustion of the GDI engine appears as peak fire temperature with different engine speeds, as illustrated in figure (5). This figure shows that a peak fire temperature is an increase when increasing engine speed at any inlet air temperatures. This behavior is satisfactory due to the less time required for heat loss.

\section{Combustion Duration}

The duration of combustion is the time between the start and finish of combustion, and it determines the overall value of fuel combustion. The influence of various inlet air temperatures on GDI engine combustion is appearing as combustion duration (deg) with altered engine speeds in figure (6). It is present that the duration of combustion is increasing when the engine speed increases at different inlet air temperatures 


\section{Effective Power (Brake Power)}

The various inlet air temperature on the performance of the GDI engine are shown in Figure (7) as an effective power (kW) with engine speed. Figure (7) shows that effective power increases with the increase in engine speed at different inlet air temperatures due to the increase in the power stroke per unit of time. Furthermore, because of the decline in volumetric efficiency, it diminishes when the incoming air temperature rises at any engine speed.

\section{Effective Torque (Brake Torque)}

When the engine is running on LPG, the change in effective torque is linked to engine speed at a constant throttle position (see Figure 8). This figure illustrates that by increasing the temperature of the inlet air, the effective torque is decreasing at any engine speed. This is due to a decrease in volumetric efficiency.

\section{Brake Specific Fuel Consumption (BSFC)}

The analysis of how the fuel can be used and transformed into a specific energy efficiency is presented in brake specific fuel consumption. The various impacts of the inlet air temperature on the performance of the GDI engine appear as specific fuel consumption $(\mathrm{g} / \mathrm{KWh})$ with engine speed (rev/min) in figure (9). This figure presents the brake specific fuel consumption is increasing when the engine speed increases at any inlet air temperature. This is due to the decrease in volumetric efficiency and combustion time.

\section{Nitrogen Oxide (NOx)}

The nitrogen oxide with engine speed is illustrated in figure (10). This figure shows the various inlet air temperature that effects on GDI engine emission fuelled with LPG fuel. Whoever, it can observe that when the inlet air temperature increasing the NOx is increasing at any engine speed. That's because of the increase in the peak fire temperature of the cylinder.

\section{Soot Emission}

The soot emission of the test engine relative to the engine speed at different inlet air temperatures when fuelled with LPG fuel is shown in figure (11). It can be observed that when the temperature of the inlet air increases the soot reduces at low engine speed, the soot increases at high engine speed. This behavior is due to increases in the peak temperature of the cylinder.

\section{CONCLUSIONS}

In this study, the AVL WORKSPACE simulation model was used as a programming language in order to investigate the gasoline direct injection (GDI) engine performance at different engine speeds at different inlet air temperatures. The following are the main findings of the current research:

1. At the same inlet air temperature, the increase in the engine speed led to the increasing up to $17 \%$ in the peak fire temperature, combustion duration, effective power and brake specific fuel consumption, while it led to the decreasing in the peak fire pressure, effective torque and oxide nitrogen around $12 \%$.

2. At the same engine speed, the increase in the inlet air temperature led to the increasing in the peak fire temperature, brake specific fuel consumption and oxide nitrogen but it led to the decreasing in the peak fire pressure, combustion duration, effective power and effective torque.

\section{Acknowledgement}

The AVL Advanced Simulation Technologies team provided important assistance to the writers of this work. 
Table 1. LPG's Chemical Structures

\begin{tabular}{|c|c|c|}
\hline Substance & $\begin{array}{l}\text { Volume-based } \\
\text { analysis }\end{array}$ & Weight of a Molecule $\mathbf{( k g / k m o l )}$ \\
\hline $\mathrm{C}_{2} \mathrm{H}_{6}$ & 0.9 & 30 \\
\hline $\mathrm{C}_{3} \mathrm{H}_{8}$ & 36.3 & 44 \\
\hline $\mathrm{C}_{4} \mathrm{H}_{10}$ & 62.3 & 58 \\
\hline $\mathrm{C}_{5} \mathrm{H}_{12}$ & 0.5 & 72 \\
\hline
\end{tabular}

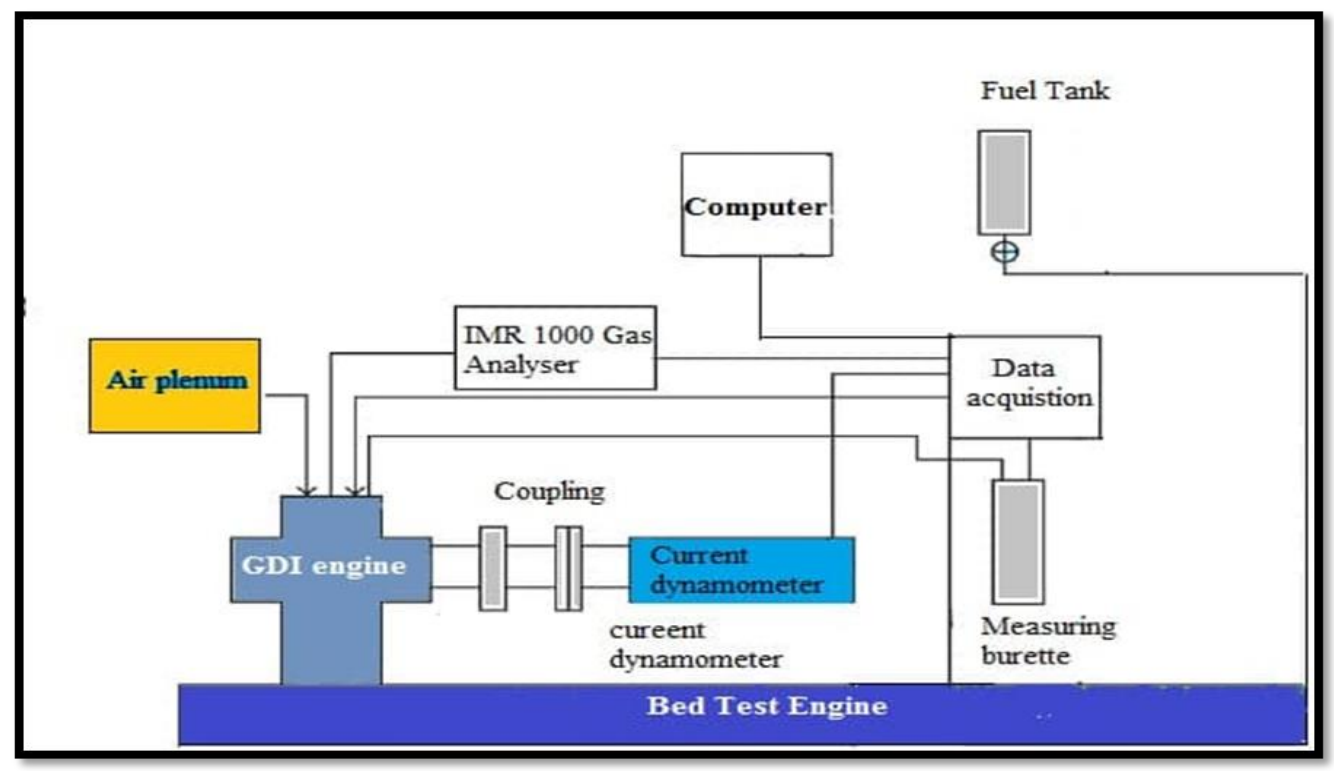

Fig.1. Test engine bench's schematic layout

Table 2. Engine specification

\begin{tabular}{|c|c|}
\hline Particulars & Specifications \\
\hline Manufacturer & Hyundai \\
\hline Engine Model & 2.0 Liter and 16 Valves \\
\hline Combustion system & GDI system \\
\hline Number of cylinders & 4 cylinders \\
\hline Bore & $81 \mathrm{~mm}$ \\
\hline Stroke & $97 \mathrm{~mm}$ \\
\hline Compression ratio (CR) & $17.5: 1(-)$ \\
\hline Max power & $118 \mathrm{~kW}$ at $5500 \mathrm{rpm}$ \\
\hline Max torque & $142 \mathrm{Nm}$ at $4600 \mathrm{rpm}$ \\
\hline
\end{tabular}




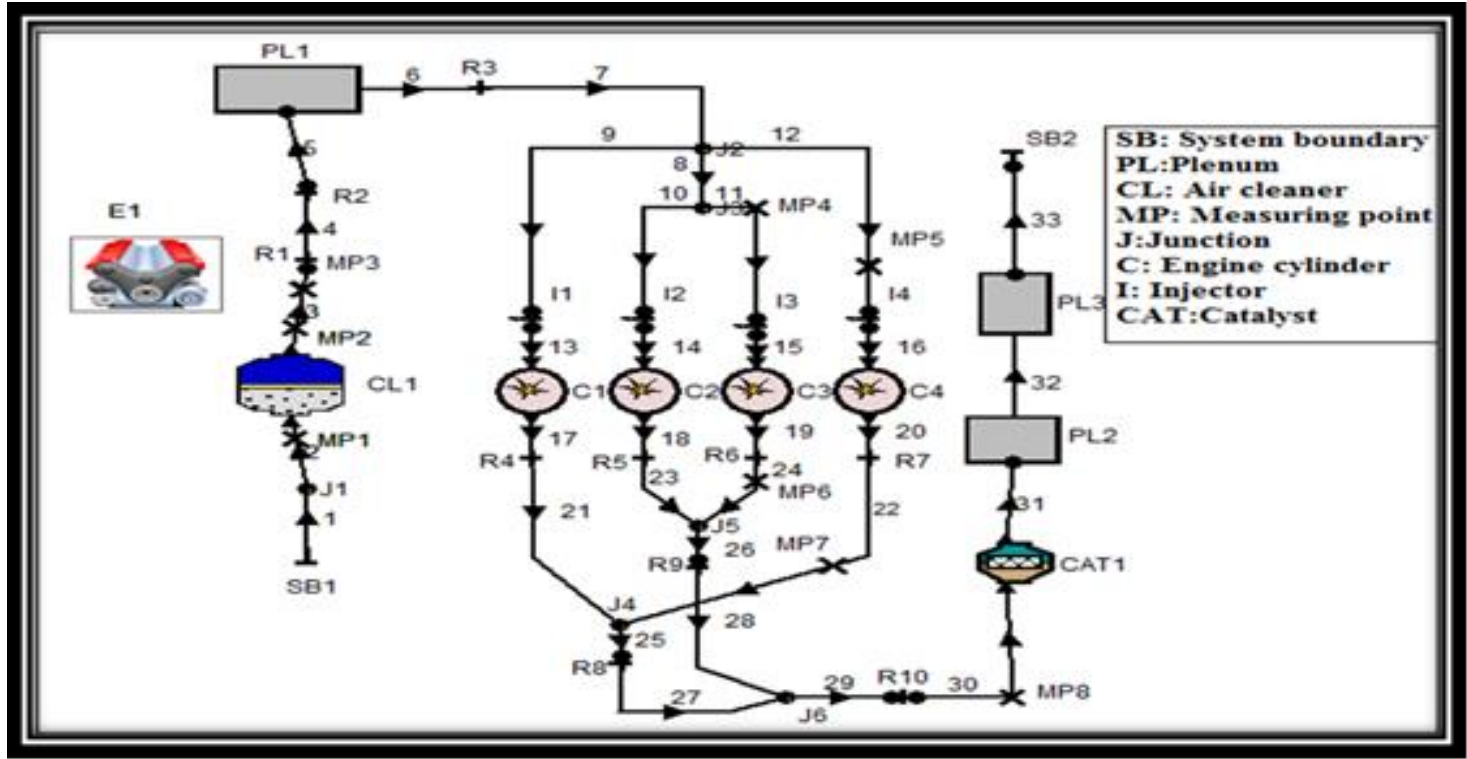

Fig.2. AVL Boost's symbolic engine model schematic

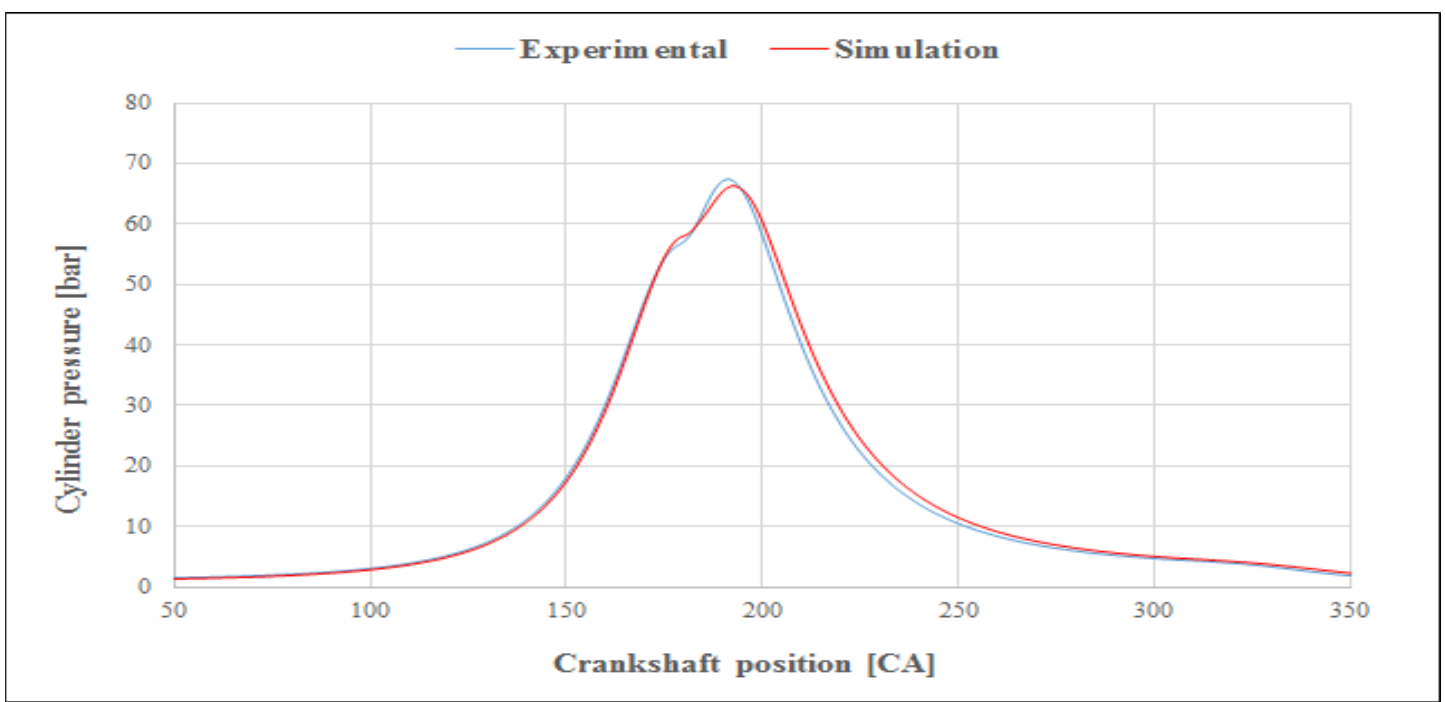

Fig.3. Comparison between experimental and simulation pressure for full load, $1500 \mathrm{rpm}$ speed

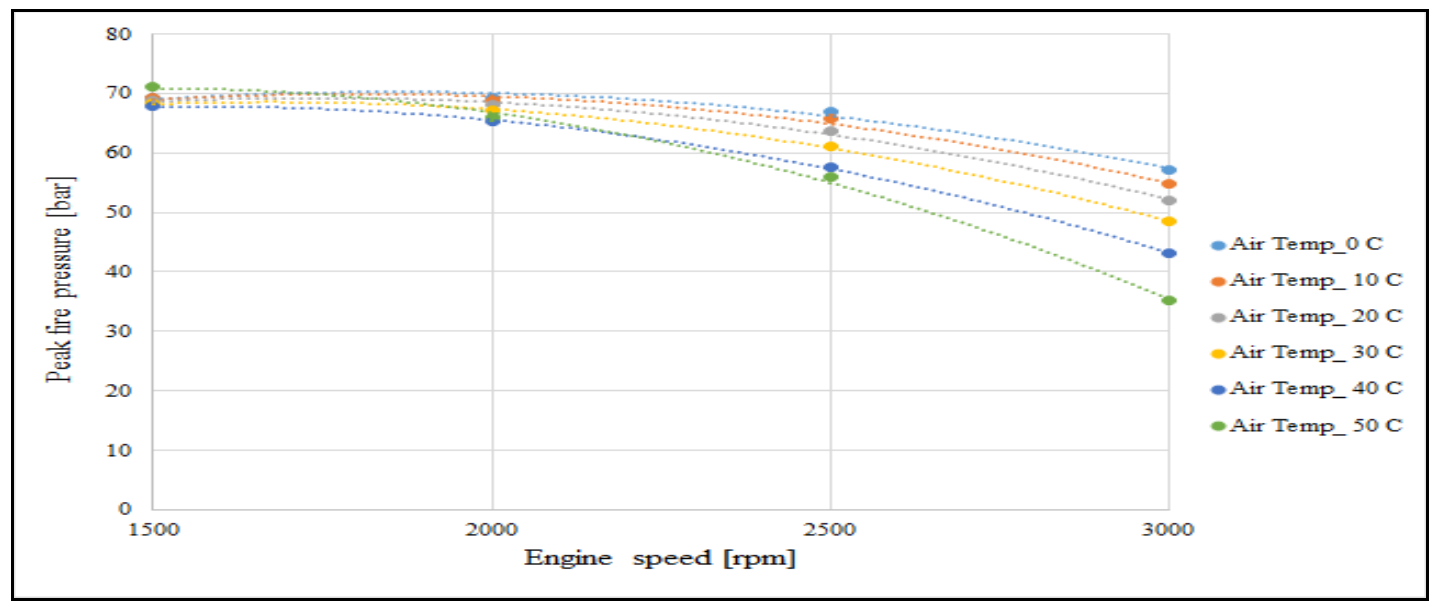

Fig.4. Peak fire pressure (bar), engine speed (rpm) for multi inlet air temperature $\left({ }^{\circ} \mathrm{C}\right)$ of GDI engine 


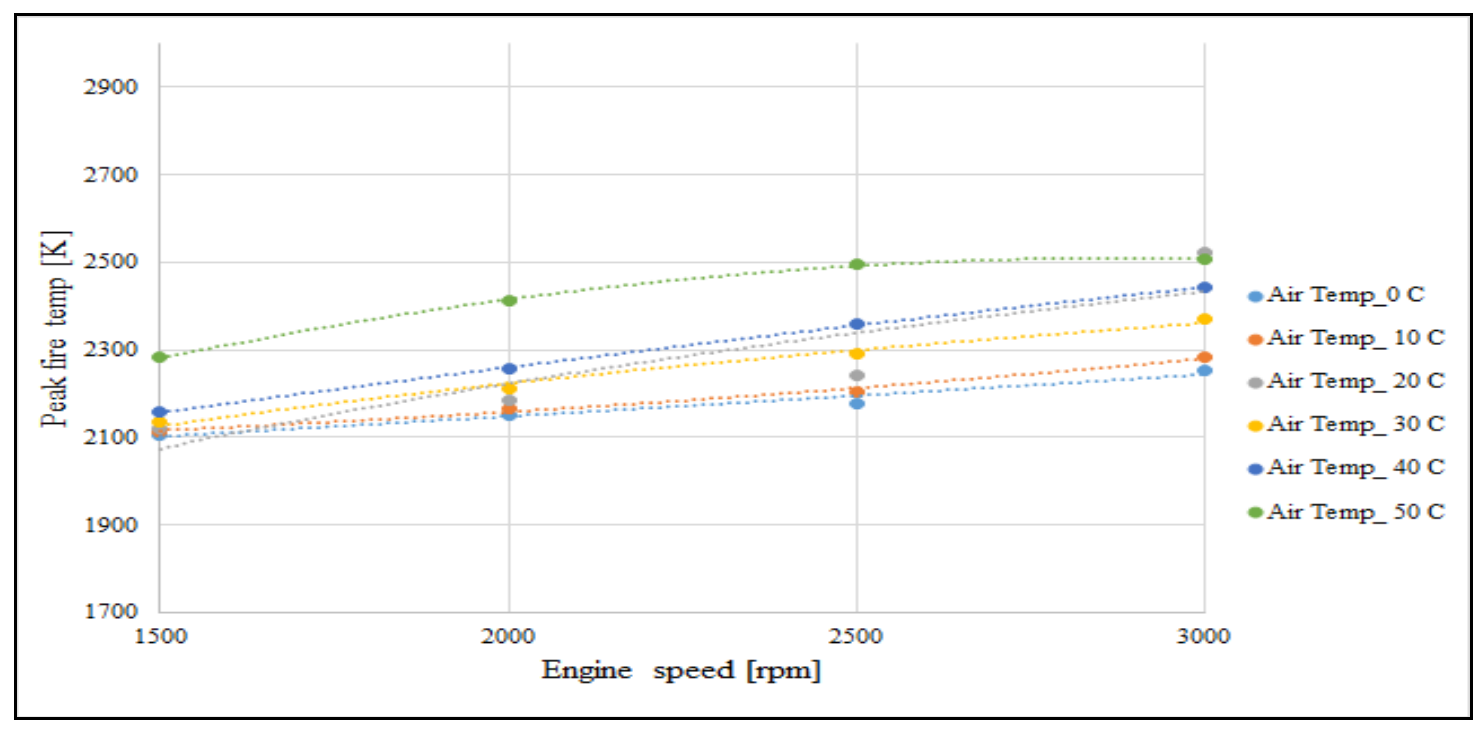

Fig.5. Peak fire temperature $(\mathrm{K})$ with engine speed (rpm) for multi inlet air temperatures $\left({ }^{\circ} \mathrm{C}\right)$ of GDI engine

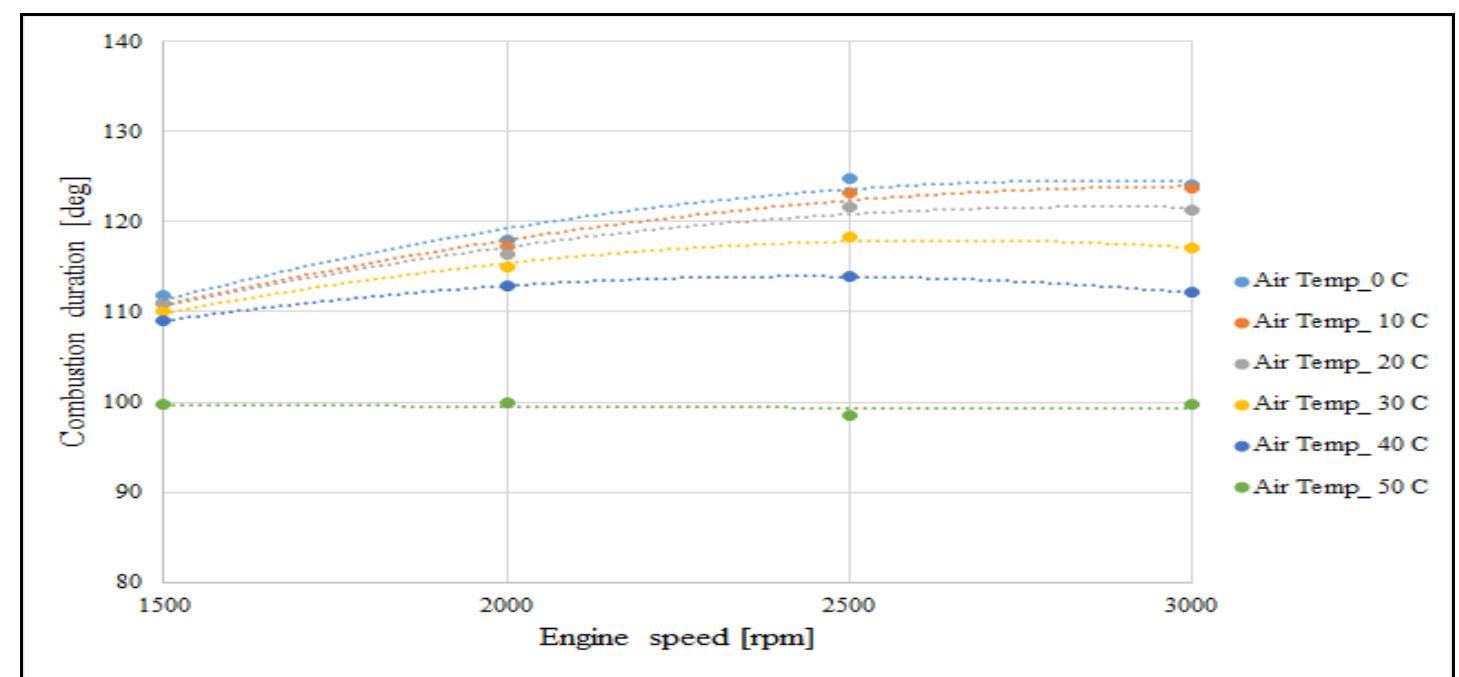

Fig.6. Combustion duration (deg.) with engine speed (rpm) for multi inlet air temperature $\left({ }^{\circ} \mathrm{C}\right)$ of GDI engine

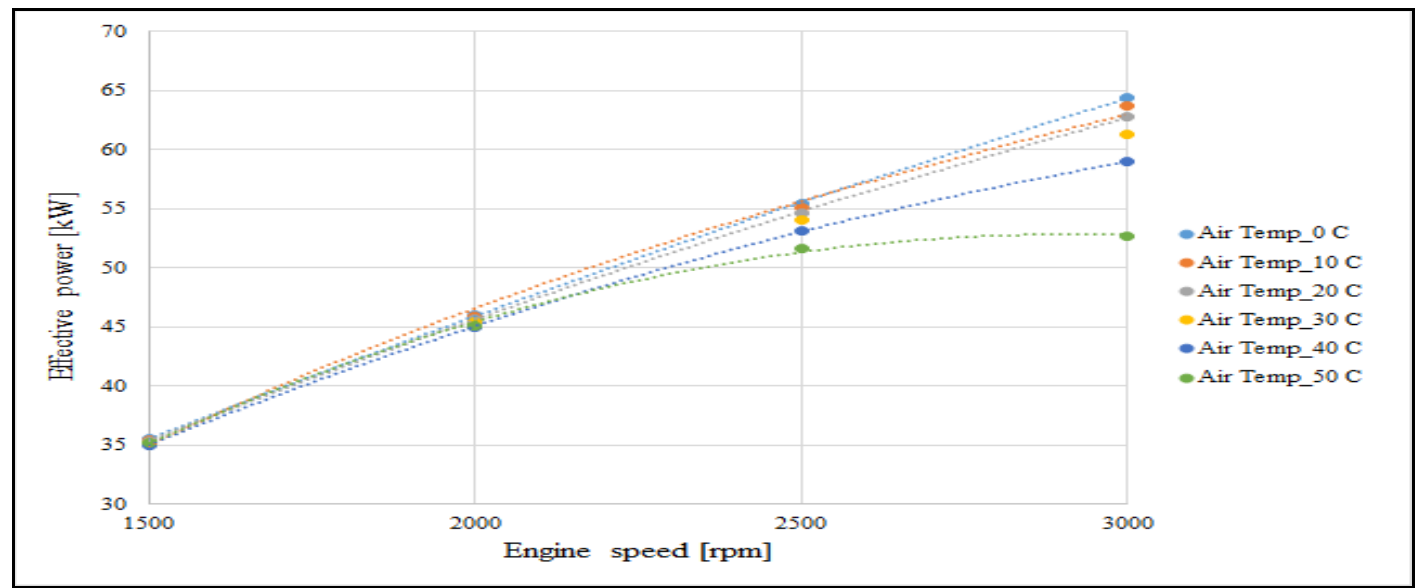

Fig.7. Effective power $(\mathrm{KW})$ with engine speed $(\mathrm{rpm})$ for multi inlet air temperature $\left({ }^{\circ} \mathrm{C}\right)$ of GDI engine 


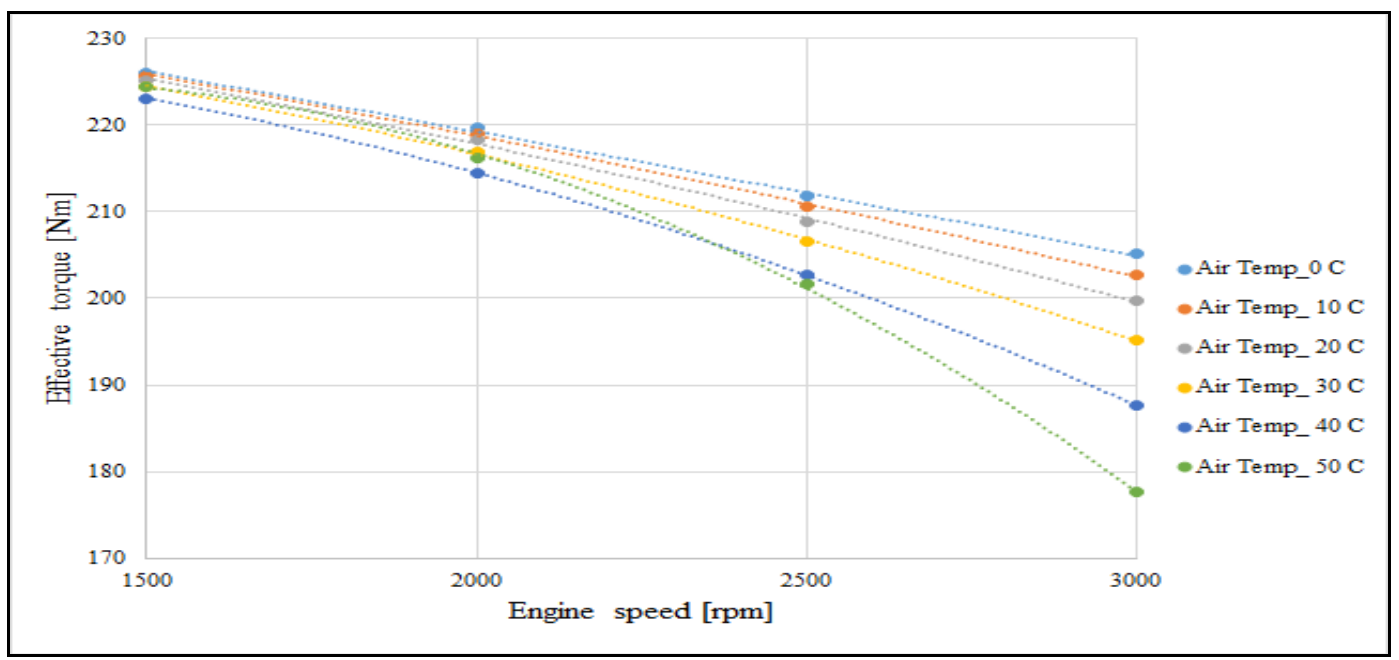

Fig.8. Effective torque $(\mathrm{Nm})$ with speed (rpm) for multi inlet air temperature $\left({ }^{\circ} \mathrm{C}\right)$ of GDI engine

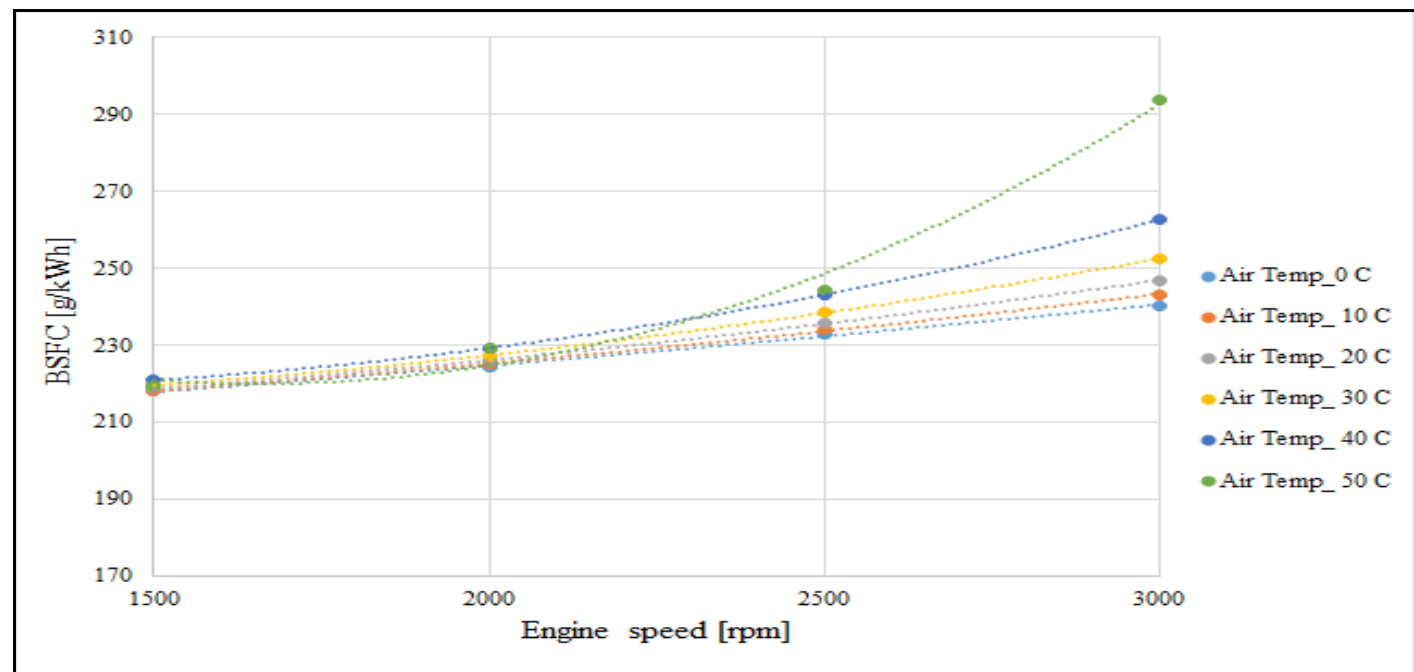

Fig.9. Break specific fuel consumption (N.m) with engine speed (rpm) for multi inlet air temperature $\left({ }^{\circ} \mathrm{C}\right)$ of GDI engine

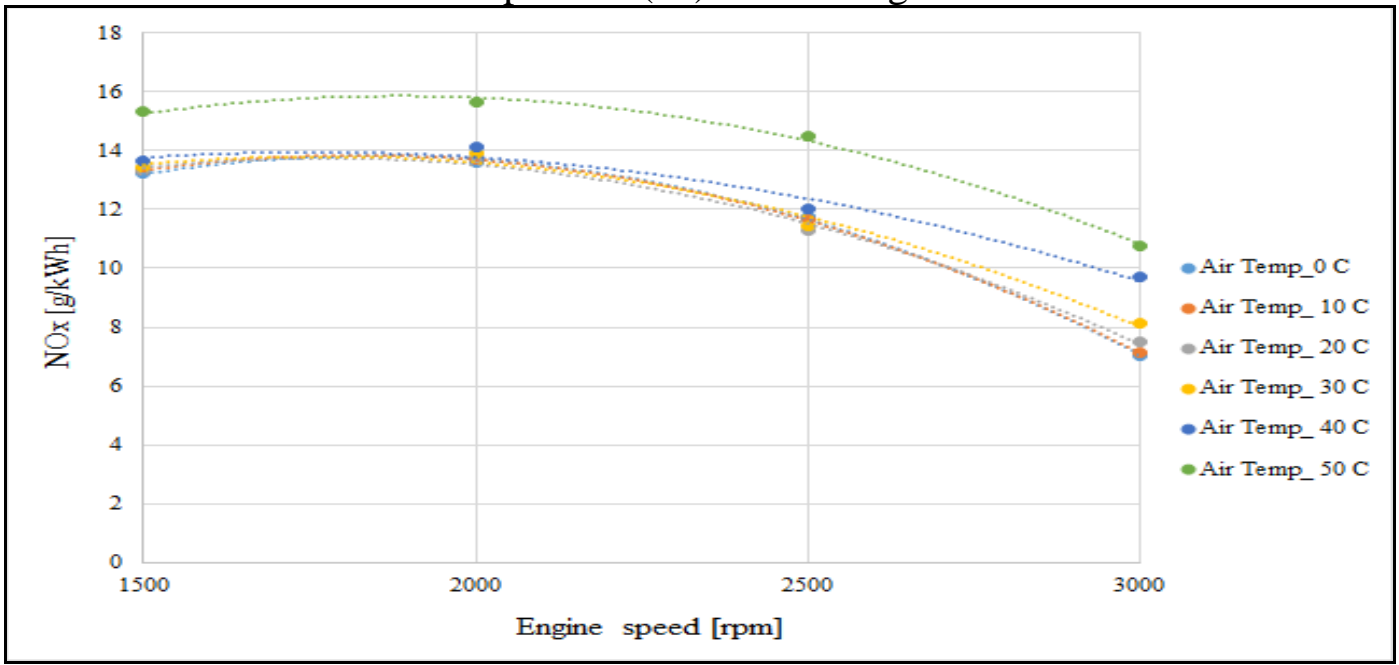

Fig.10. Oxide of nitrogen $(\mathrm{g} / \mathrm{kWh})$ with engine speed $(\mathrm{rpm})$ for multi inlet air temperature $\left({ }^{\circ} \mathrm{C}\right)$ of GDI engine 


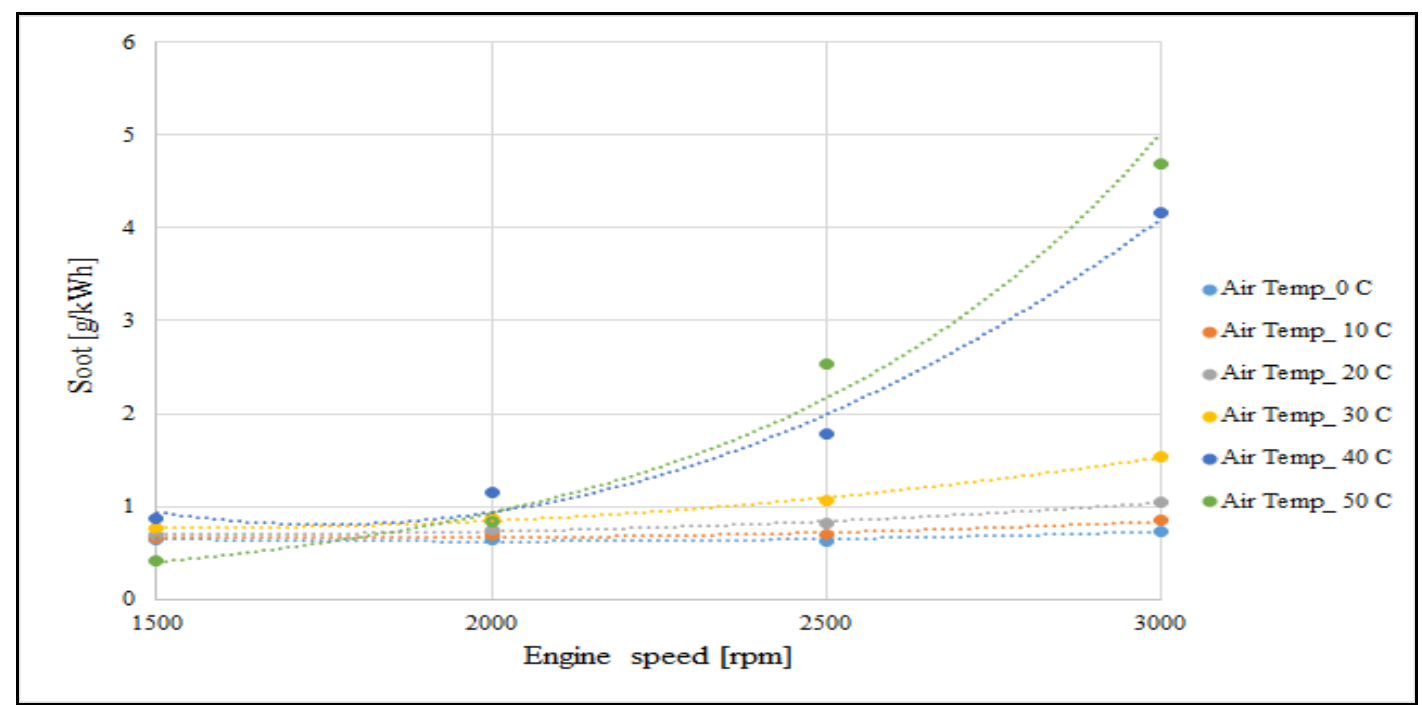

Fig.11. Soot $(\mathrm{g} / \mathrm{kWh})$ with engine speed $(\mathrm{rpm})$ for multi inlet air temperature $\left({ }^{\circ} \mathrm{C}\right)$ of GDI engine

\section{REFERENCES}

Abdalla AN, Tao H, Bagaber SA, Ali OM, Kamil M, Ma X, et al. "Prediction of emissions and performance of a gasoline engine running with fuel oil - gasoline blends using response surface methodology". Fue, Vol.1253,pp.1-14, 2019

Ali OM., "Evaluation of diesel engine performance with high blended diesel-biodiesel fuel from waste cooking oil". IOP Conference Series: Materials Science and Engineering ;518. 2019.

Ahmed AH, Ali OM, Mohammed AE, Daoud RW, Ibrahim TK,.'Enhancement of engine performance with high blended diesel-biodiesel fuel using iso-butanol additive. IOP Conference Series: Materials Science and Engineering ;518, 2019

Abdalla AN, Majeed O, Awad OI, Tao H., "Wavelet analysis of an SI engine cycle-to-cycle variations fuelled with the blending of gasoline -fusel oil at a various water content. Energy Conversion and Management", Vol.183,pp.746-52, 2019.

Ahmed Shakir, "Experimental Study of the Effect of Hydrogen Blending on Burning Velocity of Different Fuels" A Thesis in Mechanical Engineering (Power Engineering), University of Babylon,2016.

“Alternative Vehicle Fuels,” Ceres Logistics, 2004.

A.P.F. Yoong, A.P. Watkins, "Study of liquefied petroleum gas (LPG) spray modelling," ILASS-Europe 2001, Zurich, 2001.

C. L. Myung, K. Choi, J. Kim, Y. Lim, J. Lee, and S. Park, “Comparative study of regulated and unregulated toxic emissions characteristics from a spark ignition direct injection lightduty vehicle fueled with gasoline and liquid phase LPG (liquefied petroleum gas)," Energy, Vol. 44, No. 1, pp. 189-196, 2012. 
Haykan Bayraktar, Orhan Durgun, "Investigating the effects of LPG on spark ignition engine combustion and performance," Energy Conversion and Management, Vol. 46, pp. 2317-2333, 2005.

Kitae Yeom, Jinyoung Jang, Choongsik Bae, "Homogeneous charge compression ignition of LPG and gasoline using variable valve timing in an engine," Fuel, Vol. 86, pp. 494-503, 2007.

Kihyung Lee, Jeaduk Ryu, "An experimental study of the flame propagation and combustion characteristics of LPG fuel," Fuel, Vol. 84, pp. 1116-1127, 2005.

L. Raslavičius, A. Keršys, S. Mockus, N. Keršienè, and M. Starevičius, "Liquefied petroleum gas (LPG) as a medium-term option in the transition to sustainable fuels and transport," Renew. Sustain. Energy Rev., Vol. 32, pp. 513-525, Apr. 2014.

M. Masi, "Experimental analysis on a spark ignition petrol engine fuelled with LPG (liquefied petroleum gas)," Energy, Vol. 41, No. 1, pp. 252-260, May 2012.

M. Farrugia, A. Briffa, and M. Farrugia, "Liquid State LPG Conversion of an Older Vehicle," SAE Technical Paper, 2014-01-2613, 2014.

Philip Price, Shengmin Guo, Martin Hirschmann, "Performance of an evaporator for a LPG powered vehicle,” Applied Thermal Engineering, Vol. 24, pp. 1179-1194, 2004.

Ristovski, Z.D., Jayaratne, E.R., Morawska, L., Ayoko, G.A., Lim, M., "Particle and carbon dioxide emissions from passenger vehicles operating on unleaded petrol and LPG fuel," Science of the Total Environment 345,93-98, 2005.

Ross Ryskamp, " Emissions and Performance of Liquefied Petroleum Gas as a Transportation Fuel: A Review" , Ph.D. Research Assistant Professor, West Virginia University, Center for Alternative Fuels, Engines, and Emissions, World LPG Association ,October 3rd, 2017.

Schifter, I., Diaz, L., Lopez-Salinas, E., Rodriguez, R., Avalos, S., Guerrero, V., "An evaluation of the LPG vehicles program in the metropolitan area of Mexico City," Journal of the Air and Waste Management Association, Vol. 50, pp. 301-309, 2011.

Snelgrove, D.G., Dupont, P., Bonetto, R., "An investigation into the influence of LPG (autogas) composition on the exhaust emissions and fuel consumption of bi-fuelled Renault vehicles," SAE 961170, 1996. 